\title{
What is in a "Cup of Joe"? From green beans to spent grounds: a mini-review on coffee composition and health benefits
}

\author{
Giovana Bonat Celli ${ }^{*}$ and Adriano Costa de Camargo ${ }^{b}$
}

\begin{abstract}
aThe Whole Coffee Company LLC., Miami, Florida, USA
bepartamento de Ciencias Vegetales, Facultad de Agronomía e Ingeniería Forestal, Pontificia Universidad Católica de Chile, Casilla 30622, Santiago, Chile

*Corresponding author: Giovana B. Celli, The Whole Coffee Company LLC., Miami, Florida, USA. Tel: +1 (786) 364-4444;

E-mail: giovana@wholecoffee.co
\end{abstract}

DOI: $10.31665 /$ JFB.2019.6185

Received: June 07, 2019; Revised received \& accepted: June 29, 2019

Citation: Celli, G.B, and de Camargo, A.C. (2019). What is in a "Cup of Joe"? From green beans to spent grounds: a mini-review on coffee composition and health benefits. J. Food Bioact. 6: 62-67.

\begin{abstract}
Coffee is one of the most popular beverages consumed worldwide and is amongst the main dietary sources of bioactive compounds. Recent studies have described a positive association between caffeine ingestion and health, including improvement of exercise performance and enhancement of long-term memories in humans. However, from roasting to extraction, the processing of the coffee beans has a significant impact on the profile of bioactive compounds. For instance, roasting results on the reduction of 5-caffeoylquinic acid and trigonelline, while increases the concentration of melanoidins. Another important component is its lipid fraction (known as coffee oil), which can migrate to the surface of the beans and undergo changes in its composition during roasting. This mini-review presents an overview of the composition of coffee, including changes that occur during processing - from green beans to spent grounds, and recent research on its health benefits, with special focus on their antioxidant properties.
\end{abstract}

Keywords: Caffeine; Chlorogenic acid; Trigonelline; Roasting, Bioactive compounds.

\section{Introduction}

Coffee is one of the most popular beverages consumed worldwide and is amongst the main dietary sources of bioactive compounds (Pérez-Jiménez et al., 2010). The continuous increase in coffee demand could be explained by several factors, such as the improvement on the quality of beans, creation and expansion of specialty coffee shops, and dissemination of literature linking its consumption to health benefits. For instance, recent studies have described a positive association between caffeine ingestion and improvement of exercise performance (Grgic et al., 2019) and a new mode of action of this compound at the mitochondrial level with beneficial effects on cardiovascular diseases (Ale-Agha et al., 2018). In addition to the potential role of caffeine as a protective agent on Parkinson's disease, Yan et al. (2018) showed that the co-administration with eicosanoyl-5-hydroxytryptamide (another compound purified from coffee) enhanced the activity of a specific phosphatase that acts on $\alpha$-synuclein, a characteristic pathogenic protein. However, another study (with more than 340,000 individuals) showed that those who consumed more than 6 cups of coffee a day had $22 \%$ more chances of developing cardiovascular diseases than nondrinkers (11\%) and drinkers of decaffeinated coffee (7\%) (Zhou and Hyppönen, 2019).

Amongst several compounds, caffeine is recognized as the main bioactive substance in coffee. Other examples of bioactive compounds identified in coffee are shown in Table 1. Coffee accounts for approximately two-thirds of the daily intake of caffeine by US population above 10 years old (Barone and Roberts, 1996). Several health benefits have been associated with consumption of caffeine, including increased cognitive performance (Borota et al., 2014), enhancement of anti-inflammatory response (Tauler et al., 2013), hypoalgesic effects (Maridakis et al., 2007), among others shown in Table 2.

Similar to other examples in the literature, the processing 
Table 1. Screening of main bioactive compounds of coffee using LC and LC-MS

\begin{tabular}{|c|c|c|c|c|}
\hline${ }^{*}[\mathrm{M}-\mathrm{H}]^{-}$or $* *[\mathrm{M}-\mathrm{H}]^{+}$ & MS $^{n}$ & Compound & Feedstock & Reference \\
\hline $195.0877^{*}$ & 137.92 & Caffeine & $\begin{array}{l}\text { Green coffee, roasted } \\
\text { coffee, coffee powder } \\
\text { and beverage }\end{array}$ & $\begin{array}{l}\text { Abreu et al. (2011), Angeloni et al. } \\
\text { (2019), Caporaso et al. (2014), Liu } \\
\text { and Kitts (2011), Priftis et al. (2018) }\end{array}$ \\
\hline $335.0761^{*}$ & $\begin{array}{l}\text { 179.0514, } \\
161.0862,135.0232\end{array}$ & $\begin{array}{l}\text { Caffeoylquinic } \\
\text { lactone acid }\end{array}$ & $\begin{array}{l}\text { Green coffee, roasted } \\
\text { coffee, and beverages }\end{array}$ & $\begin{array}{l}\text { Angeloni et al. (2019), } \\
\text { Priftis et al. (2018) }\end{array}$ \\
\hline $337.0917^{*}$ & $\begin{array}{l}163,190.8751 \\
118.9217\end{array}$ & $\begin{array}{l}3-p \text {-coumaroylquinic } \\
\text { acid }\end{array}$ & $\begin{array}{l}\text { Green coffee and } \\
\text { roasted coffee }\end{array}$ & Priftis et al. (2018) \\
\hline $337.0917 *$ & $\begin{array}{l}163.5239,190.3598 \\
118.5912\end{array}$ & $\begin{array}{l}5-p \text {-coumaroylquinic } \\
\text { acid }\end{array}$ & $\begin{array}{l}\text { Green coffee, } \\
\text { roasted coffee, and } \\
\text { coffee beverages }\end{array}$ & $\begin{array}{l}\text { Angeloni et al. (2019), } \\
\text { Priftis et al. (2018) }\end{array}$ \\
\hline $353.0867 *$ & $191.0208,179.0095$ & 3-O-caffeoylquinic acid & $\begin{array}{l}\text { Green coffee, roasted } \\
\text { coffee, coffee beverages }\end{array}$ & $\begin{array}{l}\text { Niseteo et al. (2012), } \\
\text { Priftis et al. (2018) }\end{array}$ \\
\hline $353.0867 *$ & $191.0518,173.0086$ & 4-O-caffeoylquinic acid & $\begin{array}{l}\text { Green coffee, roasted } \\
\text { Coffee, coffee beverages }\end{array}$ & $\begin{array}{l}\text { Angeloni et al. (2019), } \\
\text { Priftis et al. (2018) }\end{array}$ \\
\hline $353.0867^{*}$ & $\begin{array}{l}\text { 191.0835, } \\
178.9312,135.0009\end{array}$ & 5-O-caffeoylquinic acid & $\begin{array}{l}\text { Green coffee, roasted } \\
\text { coffee, coffee beverages }\end{array}$ & $\begin{array}{l}\text { Angeloni et al. (2019), } \\
\text { Priftis et al. (2018) }\end{array}$ \\
\hline $367.1026 *$ & 193.1396 & 3-O-feruloylquinic acid & $\begin{array}{l}\text { Green coffee and } \\
\text { roasted coffee }\end{array}$ & Priftis et al. (2018) \\
\hline $367.1022 *$ & 193.0504 & 4-O-feruloylquinic acid & $\begin{array}{l}\text { Green coffee and } \\
\text { roasted coffee }\end{array}$ & Priftis et al. (2018) \\
\hline $367.1024 *$ & 193.0502 & 5-O-feruloylquinic acid & $\begin{array}{l}\text { Green coffee, roasted } \\
\text { coffee, and beverages }\end{array}$ & $\begin{array}{l}\text { Angeloni et al. (2019), } \\
\text { Priftis et al. (2018) }\end{array}$ \\
\hline $417^{* *}$ & 151,123 & $\beta$-Tocopherol & $\begin{array}{l}\text { Green and roasted coffee } \\
\text { and coffee beverage }\end{array}$ & Alves et al. (2009) \\
\hline $431 * *$ & 165,137 & $\alpha$-Tocopherol & $\begin{array}{l}\text { Green and roasted coffee } \\
\text { and coffee beverage }\end{array}$ & Alves et al. (2009) \\
\hline $515.1188^{*}$ & $\begin{array}{l}353.2199, \\
335.2577,173.0377\end{array}$ & $\begin{array}{l}\text { 1,5-dicaffeoylquinic } \\
\text { acid }\end{array}$ & $\begin{array}{l}\text { Green coffee and } \\
\text { roasted coffee }\end{array}$ & Priftis et al. (2018) \\
\hline 515.1188* & $\begin{array}{l}353.1824,173.0116 \\
191.0214\end{array}$ & 3,4-dicaffeoylquinicacid & $\begin{array}{l}\text { Green coffee and } \\
\text { roasted coffee }\end{array}$ & Priftis et al. (2018) \\
\hline 515.1188* & $353.1999,172.9495$ & $\begin{array}{l}\text { 2,4-dicaffeoylquinic } \\
\text { acid }\end{array}$ & $\begin{array}{l}\text { Green coffee and } \\
\text { roasted coffee }\end{array}$ & Priftis et al. (2018) \\
\hline $529.1341 *$ & $\begin{array}{l}367.2116, \\
335.1851,173.0893\end{array}$ & $\begin{array}{l}\text { Caffeoyl- } \\
\text { feruloylquinic acid }\end{array}$ & $\begin{array}{l}\text { Green coffee and } \\
\text { roasted coffee }\end{array}$ & Priftis et al. (2018) \\
\hline
\end{tabular}

*Negative mode; ** positive mode; LC, liquid chromatography; MS, mass spectrometry, may contemplate tandem mass spectrometry (MS ${ }^{n}$ )

of the coffee beans has a significant impact on the profile of bioactive compounds, from roasting to extraction. For instance, Vignoli et al. (2014) showed that the levels of 5-caffeoylquinic acid and trigonelline decreased, while melanoidins increased as the roasting progressed. Comparing brewing methods, instant coffee has a higher caffeine level than filtered and Turkish coffee (Samanidou et al., 2012). The serving size also matters: a 25$\mathrm{mL}$ espresso cup has 2.8 times less caffeine and 1.5 times less phenolic compounds than $125 \mathrm{~mL}$ of American coffee (Caporaso et al., 2014).

This review aims to present an overview of the composition of coffee, including changes that occur during processing, and recent research on its health properties. First, the chemical profile of green coffee beans is presented. This is followed by a review of the effects of roasting and extraction on the physicochemical properties of the beans. Finally, studies focused on the use of spent coffee ground generated from brewing methods as a source of value- added compounds are presented.

\section{Physicochemical properties of coffee}

Approximately 99\% of the beans of economic importance comes from two species: Coffeea arabica L. (or Arabica coffee) and $C$. canephora Pierre ex Froehner (or Robusta coffee), although more than 90 species have been identified (DaMatta and Ramalho, 2006). Some of the differences observed between Arabica and Robusta coffee are the growing requirements (Magrach and Ghazoul, 2015), physical aspects of the beans (Mendonça et al., 2009), sensory characteristics when cupped (Salamanca et al., 2017), and chemical composition before and after roasting, including caffeine content (Perrois et al., 2015), amino acid (Casal et al., 2003), and tocopherol profile (Alves et al., 2009). 
Table 2. Potential health benefits of coffee and its main bioactive compounds

\begin{tabular}{|c|c|c|}
\hline Feedstock & Main findings & Reference \\
\hline Coffee & $\begin{array}{l}\text { Lower level of spontaneous DNA strand breaks } \\
\text { in peripheral white blood cells }\end{array}$ & Bakuradze et al. (2015) \\
\hline Coffee & $\begin{array}{l}\text { Increase in the resistance of LDL to oxidative modification } \\
\text { and higher concentration of conjugated forms of } \\
\text { caffeic, } p \text {-coumaric, and ferulic acids into LDL }\end{array}$ & Natella et al. (2007) \\
\hline Coffee & Reduction of oxidative DNA damage & Bakuradze et al. (2011) \\
\hline $\begin{array}{l}\text { Coffee containing mainly chlorogenic } \\
\text { acid isomers and derivatives }\end{array}$ & $\begin{array}{l}\text { Reducing power, scavenging of superoxide and hydroxyl } \\
\text { radicals and antimutagenic activity Salmonella typhimurium }\end{array}$ & Priftis et al. (2018) \\
\hline Coffee and caffeine & $\begin{array}{l}\text { Improvement of long-term memory, reduction of lipid } \\
\text { peroxidation of brain membranes, and increased activity } \\
\text { of glutathione reductase and superoxide dismutase }\end{array}$ & Abreu et al. (2011) \\
\hline Caffeine & Enhancement of consolidation of long-term memories in humans & Borota et al. (2014) \\
\hline Caffeine & $\begin{array}{l}\text { Effect is generally greater for aerobic as } \\
\text { compared with anaerobic exercise }\end{array}$ & Grgic et al. (2019) \\
\hline Caffeine & $\begin{array}{l}\text { Attenuation of delayed-onset muscle pain and } \\
\text { force loss following eccentric exercise }\end{array}$ & Maridakis et al. (2007) \\
\hline $\begin{array}{l}\text { Caffeoylquinic and } \\
\text { dicaffeoylquinic acid isomers }\end{array}$ & DNA-protective effects & Xu et al. (2012) \\
\hline
\end{tabular}

In addition to inter-species differences, the biochemical composition and quality attributes of coffee can be affected by growing conditions, including shading (Somporn et al., 2012), altitude (Worku et al., 2018), and temperature (Bertrand et al., 2012). This section will present the physicochemical and bioactive properties of coffee, from green beans to the cup, including changes that occur during processing. Focus will be given to Arabica coffee, unless otherwise stated.

\subsection{Green beans to roasted coffee}

One of the main components in green coffee beans is the lipid fraction (or coffee oil), which is comprised of approximately $75 \%$ of triacylglycerols (e.g., stearic and oleic acids), up to $20 \%$ total free and esterified diterpene alcohols (e.g., kahweol and cafestol, both associated with positive and negative health effects) (Speer and Kölling-Speer, 2006), 5\% total free and esterified sterols (e.g., sitosterol and stigmasterol), and a small amount of minor compounds (e.g., tocopherols) (Sunarharum et al. 2014). With roasting, the oil fraction can migrate to the surface of the beans and undergo changes in its composition. Although sterols and most triacylglycerols are mainly unaffected (Speer and Kölling-Speer, 2006; Sunarharum et al., 2014), Kocadağl1 et al. (2012) showed that there is a linear increase in lipid oxidation products as the roasting progresses.

Most research on green coffee has focused on their antioxidant capacity and phenolic content, especially in terms of chlorogenic acids (or caffeoylquinic acid derivatives, CQA), which confers a sweet and oily odor to green beans. Green coffee is the main source of CQA in nature $(5-12 \mathrm{~g} / 100 \mathrm{~g})$, and more than $30 \%$ of the ingested dose is observed in plasma around 0.5 to $8 \mathrm{~h}$ (as native compound or metabolites) after consumption of green coffee extract (Farah et al., 2008). According to Zhao et al. (2012), caffeic acid3-O-sulfate, di-hydroferulic acid-4- $O$-sulfate, and di-hydrocaffeic acid-3-O-sulfate are the main metabolites of CQA in blood circulation. These compounds have been associated with several health benefits, mostly related to their antioxidant activity (Tajik et al.,
2017; Zhao et al., 2012). Therefore, due to their protective effect against DNA damage and LDL-cholesterol oxidation (Bakuradze et al., 2015; Natella et al., 2007), phenolics from coffee may prevent certain types of cancer and decrease the risk of heart disease.

Green coffee beans also have approximately 5\%(w/w) total inorganic element content, including potassium (mean 6714.5 $\mu \mathrm{g} / \mathrm{g})$, magnesium $(1373.9 \mu \mathrm{g} / \mathrm{g})$, calcium $(560.2 \mu \mathrm{g} / \mathrm{g})$, phosphorus $(559.1 \mu \mathrm{g} / \mathrm{g})$, aluminum $(25.9 \mu \mathrm{g} / \mathrm{g})$, and copper $(12.1 \mu \mathrm{g} / \mathrm{g})$. It was also noted that preparation of green coffee by the Turkish method was more effective on leaching the elements in comparison to mud coffee (Şemen et al., 2017). In another study, Stelmach et al. (2015) showed that the leachability of calcium and magnesium is higher for green coffee infusions than those prepared with roasted beans possibly due to a stronger binding of these elements to certain compounds formed during roasting.

Roasting of coffee beans occurs at temperatures of $180-250{ }^{\circ} \mathrm{C}$ for up to $25 \mathrm{~min}$, depending on the desired characteristics of the final product. During this process, the beans go through several physicochemical changes that can have an impact on its chemical composition and bioactive properties. For instance, a considerable amount of phenolic antioxidants found in green beans is thermally degraded or converted during roasting; however, Maillard reaction results on the formation of certain compounds (e.g., melanoidins) that also exhibit antioxidant activity (Liu and Kitts, 2011). In certain cases, roasting could enhance the antimutagenic activity of coffee (Priftis et al., 2018). Unlike phenolic compounds, caffeine is thermostable, and no significant changes on its concentration during roasting are observed (Vignoli et al., 2014).

In relation to flavor and aroma, more than 1,000 volatile compounds have been identified to date, some of which have biological properties and are responsible for coffee's sensory characteristics. For instance, beans produced from immature cherries or Robusta coffee are often qualified as being of lower sensory quality in parts due to the high levels of phenols, N-heterocyclic compounds (e.g., pyrazines) that confer "earthy" notes, and low amounts of carbohydrate degradation products associated with "sweet" and "caramel" notes (Velásquez et al., 2019) 


\subsection{Bioactive compounds in coffee brew}

Different methods (including variations on coffee/water proportion, grind size, water temperature, pressure, and extraction time) are used for the preparation of coffee beverages. Similar to roasting, they have a significant impact on the physicochemical properties and bioactive compounds extracted from the beans. Rao and Fuller (2018) compared the acidity, antioxidant activity, and concentration of CQA isomers in light roast coffee prepared by hot and cold brew methods. The main difference observed was the higher antioxidant activity of hot brews, possibly due to higher efficiency in extracting non-deprotonated acids than the cold method. In relation to caffeine content, Fuller and Rao (2017) found that its concentration was significantly higher in cold brew prepared with coarse coffee grind (medium and dark roast) than by hot extraction, as the cold extraction occurs for prolonged periods of time.

In another study, Niseteo et al. (2012) evaluated coffee brews prepared by espresso, Turkish/Greek, instant, and filter methods. Overall, instant coffee had the highest total phenolic and flavonoid contents measured as gallic acid equivalents (GAE) $(17,307 \mathrm{mg}$ $\mathrm{GAE} / \mathrm{L}$ and $8,460 \mathrm{mg} \mathrm{GAE} / \mathrm{L}$, respectively), whereas the lowest concentration was found in filtered brew $(2,967 \mathrm{mg}$ GAE/L and $1,633 \mathrm{mg} \mathrm{GAE} / \mathrm{L}$, respectively). These results are in agreement with the antioxidant activity. Niseteo et al. (2012) also investigated the addition of milk to the brews and noted that it decreased the total phenolic content, as a potential result of protein-phenolic interaction. Another factor that Niseteo et al. (2012) investigated was the reheating of Turkish/Greek coffee to a boiling state, which resulted in significant increase of CGA (amount depended on the compound) and caffeine (from 1,942.4 to $2,551.6 \mathrm{mg} / \mathrm{L}$ ) in comparison to the sample before heat treatment.

Angeloni et al. (2019) also compared different preparation methods, namely Espresso, Moka, French press, and three filter coffee (cold brew, V60, and Aeropress). Coffee brews prepared by the Espresso method had the highest content of caffeine and CGA than Moka and filtered coffees. These authors reported the results in three ways/units: concentration $(\mathrm{mg} / \mathrm{mL})$, extraction efficiency (mg/g ground coffee), and content per cup ( $\mathrm{mg} / \mathrm{cup})$. In relation to caffeine concentration, the highest content was found for samples prepared by the Espresso method (average $4.1 \mathrm{mg} / \mathrm{mL}$ ), whereas the lowest was obtained with Aeropress $(0.78 \mathrm{mg} / \mathrm{mL})$. Espresso samples also presented the highest concentration of CGA $(0.2 \mathrm{mg}$ / $\mathrm{mL}$ ). In terms of extraction efficiency, Espresso coffee had significantly higher concentration of caffeine $(17.4 \mathrm{mg} / \mathrm{g})$ and CGA $(0.77$ $\mathrm{mg} / \mathrm{g}$ ). The content per cup assumes a standard volume established by the authors based on the usual consumption of a given brew. In this case, a 120 -mL cup of cold brew coffee had $149.5 \mathrm{mg}$ of caffeine, whereas a $30-\mathrm{mL}$ cup of espresso had $122.4 \mathrm{mg}$.

These are some examples of reports in the literature that demonstrate the complexity in determining the composition or establishing a method to prepare a cup of coffee. Despite this, studies have demonstrated that the consumption of coffee brew or extracts have positive effects on health. For instance, an animal study carried out by Abreu et al. (2011) showed that the intake of coffee or caffeine for 80 days ( 20 or $40 \mathrm{mg}$ caffeine $/ \mathrm{kg} /$ day) improved longterm memory, reduced lipid peroxidation of brain membranes, and increased the concentration of reduced-glutathione.

\subsection{Functional value of spent coffee ground}

Although brewing methods are efficient in extracting most of the caffeine and CGA from coffee beans, certain compounds are not easily extracted and are discarded as spent grounds. Therefore, similar to other agro-industrial waste (de Camargo et al., 2018; Shahidi et al., 2019), spent coffee could be a valuable source of bioactive compounds. Bravo et al. (2013) investigated different processing conditions on the extraction of bioactive compounds from spent coffee, including different solvent systems, number of extraction cycles, $\mathrm{pH}$, etc. The authors found that extraction with water at neutral $\mathrm{pH}$ using a coffee machine at a ratio of $24 \mathrm{~g}$ of spent coffee to $400 \mathrm{~mL}$ of liquid resulted in the highest antioxidant activity, indicating that this product can still be a source of bioactive compounds (Bravo et al., 2013). Spent coffee obtained from coffee shop have approximately $17.7 \mathrm{mg} \mathrm{GAE} / \mathrm{g}$, whereas samples from capsules/pods have around $21.6 \mathrm{mg} \mathrm{GAE} / \mathrm{g}$ (Zuorro and Lavecchia, 2012).

The production of soluble (or instant) coffee is another process that generates a considerable amount of spent grounds, which can retain approximately $70 \%$ of the polysaccharides found in the beans. This is because most of the galactomannans and arabinogalactans present in the coffee are not extracted during various stages of coffee production (roasting and brewing) and remain bound to the spent ground matrix (Campos-Vega et al., 2015). Using an alkali pretreatment, Ballesteros et al. (2015) identified the saccharide moieties present in the spent coffee, as follows: $60.3 \% \mathrm{~mol}$ galactose, $19.9 \% \mathrm{~mol}$ arabinose, $15.4 \% \mathrm{~mol}$ glucose, and $4.4 \% \mathrm{~mol}$ mannose. Overall, the polysaccharides were thermostable, and the extract prepared from spent ground presented antioxidant activity assessed by different methods and high antimicrobial activity against fungi Phoma violacea and Cladosporium cladosporioides (Ballesteros et al., 2015). Spent ground also contains proteins (average $13.6 \%$ ), melanoidins (16\%), lipids (up to $20 \%$ ), and minerals (1.6\%) (Campos-Vega et al., 2015). The quantities vary depending on the coffee origin, roasting level, brew method, and extraction method used for characterization.

\section{Conclusion}

Coffee is one of the most important sources of bioactive compounds in modern diet, and its demand continues to grow. Caffeine is the most known bioactive compound from coffee and has been associated with several health benefits beyond energy and performance. Another important class of compounds is chlorogenic acids. Although changes occur during processing of green beans, roasted coffee still contains relevant amounts of CGA. Several reports have been published over the years with conflicting effects of coffee consumption on human health; however, recent studies have highlighted the benefits of moderate consumption (below six cups). This review also showed spent coffee ground can be used for the extraction of value-added compounds which would be otherwise discarded or composted.

\section{Conflict of interest}

There are no conflicts to declare.

\section{References}

Abreu, R.V., Silva-Oliveira, E.M., Moraes, M.F.D., Pereira, G.S., and MoraesSantos, T. (2011). Chronic coffee and caffeine ingestion effects on the cognitive function and antioxidant system of rat brains. Pharmacol. Biochem. Behav. 99: 659-664. 
Ale-Agha, N., Goy, C., Jakobs, P., Spyridopoulos, I., Gonnissen, S., DyballaRukes, N., Aufenvenne, K., von Ameln, F., Zurek, M., Spannbrucker, T., Eckermann, O., Jakob, S., Gorressen, S., Abrams, M., Grandoch, M., Fischer, J.W., Kohrer, K., Deenen, R., Unfried, K., Altschmied, J., and Haendeler, J. (2018). CDKN1B/p27 is localized in mitochondria and improves respiration-dependent processes in the cardiovascular system-New mode of action for caffeine. PLoS Biol. 16: e2004408.

Alves, R.C., Casal, S., Alves, M.R., and Oliveira, M.B. (2009). Discrimination between arabica and robusta coffee species on the basis of their tocopherol profiles. Food Chem. 114: 295-299.

Angeloni, G., Guerrini, L., Masella, P., Bellumori, M., Daluiso, S., Parenti, A., and Innocenti, M. (2019). What kind of coffee do you drink? An investigation on effects of eight different extraction methods. Food Res. Int. 116: 1327-1335.

Bakuradze, T., Boehm, N., Janzowski, C., Lang, R., Hofmann, T., Stockis, J.P., Albert, F.W., Stiebitz, H., Bytof, G., Lantz, I., Baum, M., and Eisenbrand, G. (2011). Antioxidant-rich coffee reduces DNA damage, elevates glutathione status and contributes to weight control: results from an intervention study. Mol. Nutr. Food Res. 55: 793-7.

Bakuradze, T., Lang, R., Hofmann, T., Eisenbrand, G., Schipp, D., Galan, J., and Richling, E. (2015). Consumption of a dark roast coffee decreases the level of spontaneous DNA strand breaks: a randomized controlled trial. Eur. J. Nutr. 54: 149-156.

Ballesteros, L.F., Cerqueira, M.A., Teixeira, J.A., and Mussatto, S.I. (2015). Characterization of polysaccharides extracted from spent coffee grounds by alkali pretreatment. Carbohydr. Polym. 127: 347-354.

Barone, J.J., and Roberts, H.R. (1996). Caffeine consumption. Food Chem. Toxicol. 34: 119-129.

Bertrand, B., Boulanger, R., Dussert, S., Ribeyre, F., Berthiot, L., Descroix, F., and Joët, T. (2012). Climatic factors directly impact the volatile organic compound fingerprint in green Arabica coffee bean as well as coffee beverage quality. Food Chem. 135: 2575-2583.

Borota, D., Murray, E., Keceli, G., Chang, A., Watabe, J.M., Ly, M., Toscano, J.P., and Yassa, M.A. (2014). Post-study caffeine administration enhances memory consolidation in humans. Nat. Neurosci. 17: 201-203.

Bravo, J., Monente, C., Juániz, I., De Peña, M.P., and Cid, C. (2013). Influence of extraction process on antioxidant capacity of spent coffee. Food Res. Int. 50: 610-616.

Campos-Vega, R., Loarca-Piña, G., Vergara-Castañeda, H.A., and Oomah, B.D. (2015). Spent coffee grounds: A review on current research and future prospects. Trends Food Sci. Technol. 45: 24-36.

Caporaso, N., Genovese, A., Canela, M.D., Civitella, A., and Sacchi, R. (2014). Neapolitan coffee brew chemical analysis in comparison to espresso, moka and American brews. Food Res. Int. 61: 152-160.

Casal, S., Alves, M.R., Mendes, E., Oliveira, M.B.P.P., and Ferreira, M.A. (2003). Discrimination between arabica and robusta coffee species on the basis of their amino acid enantiomers. J. Agric. Food Chem. 51: 6495-6501.

DaMatta, F.M., and Ramalho, J.D.C. (2006). Impacts of drought and temperature stress on coffee physiology and production: a review. Braz. J. Plant Physiol. 18: 55-81.

de Camargo, A.C., Schwember, A.R., Parada, R., Garcia, S., Maróstica Junior, M.R., Franchin, M., Regitano-d'Arce, M.A.B., and Shahidi, F. (2018). Opinion on the hurdles and potential health benefits in value-added use of plant food processing by-products as sources of phenolic compounds. Int. J. Mol. Sci. 19: 3498.

Farah, A., Monteiro, M., Donangelo, C.M., and Lafay, S. (2008). Chlorogenic acids from green coffee extract are highly bioavailable in humans. J. Nutr. 138: 2309-2315.

Fuller, M., and Rao, N.Z. (2017). The effect of time, roasting temperature, and grind size on caffeine and chlorogenic acid concentrations in cold brew coffee. Sci. Rep. 7: 17979.

Grgic, J., Grgic, I., Pickering, C., Schoenfeld, B.J., Bishop, D.J., and Pedisic, Z. (2019). Wake up and smell the coffee: caffeine supplementation and exercise performance-an umbrella review of 21 published metaanalyses. Br. J. Sports Med. doi:10.1136/bjsports-2018-100278.

Kocadağlı, T., Göncüoğlu, N., Hamzalıŏlu, A., and Gökmen, V. (2012). In depth study of acrylamide formation in coffee during roasting: role of sucrose decomposition and lipidoxidation. Food Funct. 3: 970-975.

Liu, Y., and Kitts, D.D. (2011). Confirmation that the Maillard reaction is the principle contributor to the antioxidant capacity of coffee brews.
Food Res. Int. 44: 2418-2424.

Magrach, A., and Ghazoul, J. (2015). Climate and pest-driven geographic shifts in global coffee production: Implications for forest cover, biodiversity and carbon storage. PLoS One 10: e0133071.

Maridakis, V., O'Connor, P.J., Dudley, G.A., and McCully, K.K. (2007). Caffeine attenuates delayed-onset muscle pain and force loss following eccentric exercise. J. Pain 8: 237-243.

Mendonça, J.C.F., Franca, A.S., and Oliveira, L.S. (2009). Physical characterization of non-defective and defective Arabica and Robusta coffees before and after roasting. J. Food Eng. 92: 474-479.

Natella, F., Nardini, M., Belelli, F., and Scaccini, C. (2007). Coffee drinking induces incorporation of phenolic acids into LDL and increases the resistance of LDL to ex vivo oxidation in humans. Am. J. Clin. Nutr. 86(3): 604-609.

Niseteo, T., Komes, D., Belščak-Cvitanović, A., Horžić, D., and Budeč, M. (2012). Bioactive composition and antioxidant potential of different commonly consumed coffee brews affected by their preparation technique and milk addition. Food Chem. 134: 1870-1877.

Pérez-Jiménez, J., Neveu, V., Vos, F., and Scalbert, A. (2010). Identification of the 100 richest dietary sources of polyphenols: an application of the Phenol-Explorer database. Eur. J. Clin. Nutr. 64: S112-S120.

Perrois, C., Strickler, S.R., Mathieu, G., Lepelley, M., Bedon, L., Michaux, S., Husson, J., Mueller, L., and Privat, I. (2015). Differential regulation of caffeine metabolism in Coffea arabica (Arabica) and Coffea canephora (Robusta). Planta 241: 179-191.

Priftis, A., Mitsiou, D., Halabalaki, M., Ntasi, G., Stagos, D., Skaltsounis, L.A., and Kouretas, D. (2018). Roasting has a distinct effect on the antimutagenic activity of coffee varieties. Mutat. Res. Gen. Tox. En. 829-830: 33-42.

Rao, N.Z., and Fuller, M. (2018). Acidity and antioxidant activity of cold brew coffee. Sci. Rep. 8: 16030.

Salamanca, C.A., Fiol, N., González, C., Saez, M., and Villaescusa, I. (2017). Extraction of espresso coffee by using gradient of temperature. Effect on physicochemical and sensorial characteristics of espresso. Food Chem. 214: 622-630.

Samanidou, V., Tsagiannidis, A., and Sarakatsianos, I. (2012). Simultaneous determination of polyphenols and major purine alkaloids in Greek Sideritis species, herbal extracts, green tea, black tea, and coffee by high-performance liquid chromatography-diode array detection. J. Sep. Sci. 35: 608-615.

Şemen, S., Mercan, S., Yayla, M., and Açıkkol, M. (2017). Elemental composition of green coffee and its contribution to dietary intake. Food Chem. 215: 92-100.

Shahidi, F., Varatharajan, V., Oh, W.Y., and Peng, H. (2019). Phenolic compounds in agri-food by-products, their bioavailability and health effects. J. Food Bioact. 5: 57-119.

Somporn, C., Kamtuo, A., Theerakulpisut, P., and Siriamornpun, S. (2012). Effect of shading on yield, sugar content, phenolic acids and antioxidant property of coffee beans (Coffea arabica L. cv. Catimor) harvested from north-eastern Thailand. J. Sci. Food Agric. 92: 1956-1963.

Speer, K., and Kölling-Speer, I. (2006). The lipid fraction of the coffee bean. Braz. J. Plant Physiol. 18: 201-216.

Stelmach, E., Pohl, P., and Szymczycha-Madeja, A. (2015). The content of $\mathrm{Ca}, \mathrm{Cu}, \mathrm{Fe}, \mathrm{Mg}$ and $\mathrm{Mn}$ and antioxidant activity of green coffee brews. Food Chem. 182: 302-308.

Sunarharum, W.B., Williams, D.J., and Smyth, H.E. (2014). Complexity of coffee flavor: A compositional and sensory perspective. Food Res. Int. 62: 315-325.

Tajik, N., Tajik, M., Mack, I., and Enck, P. (2017). The potential effects of chlorogenic acid, the main phenolic components in coffee, on health: a comprehensive review of the literature. Eur. J. Nutr. 56: 2215-2244.

Tauler, P., Martínez, S., Moreno, C., Monjo, M., Martínez, P., and Aguiló, A. (2013). Effects of caffeine on the inflammatory response induced by a 15-km run competition. Med. Sci. Sports Exerc. 45: 1269-1276.

Velásquez, S., Peña, N., Bohórquez, J.C., Gutierrez, N., and Sacks, G.L. (2019). Volatile and sensory characterization of roast coffees - Effects of cherry maturity. Food Chem. 274: 137-145.

Vignoli, J.A., Viegas, M.C., Bassoli, D.G., and Benassi, M.T. (2014). Roasting process affects differently the bioactive compounds and the antioxidant activity of arabica and robusta coffees. Food Res. Int. 61: 279-285. 
Worku, M., de Meulenaer, B., Duchateau, L., and Boeckx, P. (2018). Effect of altitude on biochemical composition and quality of green arabica coffee beans can be affected by shade and postharvest processing method. Food Res. Int. 105: 278-285.

Xu, J.-G., Hu, Q.-P., and Liu, Y. (2012). Antioxidant and DNA-protective activities of chlorogenic acid isomers. J. Agric. Food Chem. 60: 1162511630.

Yan, R., Zhang, J., Park, H.-J., Park, E.S., Oh, S., Zheng, H., Junn, E., Voronkov, M., Stock, J.B., and Mouradian, M.M. (2018). Synergistic neuroprotection by coffee components eicosanoyl-5-hydroxytryptamide and caffeine in models of Parkinson's disease and DLB. PNAS 115:
E12053-E12062.

Zhao, Y., Wang, J., Ballevre, O., Luo, H., and Zhang, W. (2012). Antihypertensive effects and mechanisms of chlorogenic acids. Hypertens. Res. 35: $370-374$

Zhou, A., and Hyppönen, E. (2019). Long-term coffee consumption, caffeine metabolism genetics, and risk of cardiovascular disease: a prospective analysis of up to 347,077 individuals and 8368 cases. Am. J. Clin. Nutr. 109: 509-516.

Zuorro, A., and Lavecchia, R. (2012). Spent coffee grounds as a valuable source of phenolic compounds and bioenergy. J. Clean. Prod. 34: 49-56. 